\title{
Virus Induced Diabetes and the Immune System
}

\author{
I. Suggestion that Appearance of Diabetes Depends on Immune Reactions* \\ F. K. Jansen ${ }^{1}$, H. Müntefering ${ }^{2}$, and W. A. K. Schmidt ${ }^{3}$ \\ ${ }^{1}$ Diabetes Research Institute, ${ }^{2}$ Pathological Institute, and ${ }^{3}$ Institute for Medical Microbiology and Virology of the University, \\ Düsseldorf
}

\begin{abstract}
Summary. The participation of immune reactions in the EMC virus induced diabetes of the mouse was studied by immunosuppression with $500 \mathrm{R}$ sublethal $\mathrm{X}$-irradiation or $120 \mathrm{mg} / \mathrm{kg}$ Asta 5122, a cyclophosphamide derivative. Average glucose levels after Xirradiation and infection remained normal, while virus infected, otherwise untreated mice, had significantly higher mean glucose levels, indicating that immune reactions are necessary for the development of virus induced diabetes. Immune suppression by the cyclophosphamide derivative led, in contrast, to a significantly increased mean glucose level and increased insulitis in comparison with the controls only infected. This indicates an important role of the cellular immune reaction, insulitis, in the destruction of the islets.
\end{abstract}

Key words: Encephalomyocarditis virus, diabetes mellitus, virus induced experimental diabetes, immune reaction, $\mathrm{X}$-irradiation, immunosuppression, cyclophosphamide, blood glucose, insulitis.

In the pathogenesis of juvenile diabetes immune reactions may play a role for the following reasons:

a) autoantibodies directed against the islets of Langerhans were found in a high percentage of juvenile diabetics $[1,2]$;

b) at the onset of severe juvenile diabetes lymphocytic infiltrations were found in the islets of Langerhans [3];

c) juvenile diabetes correlates with some HL-A antigens depending on the histocompatibility com-

\footnotetext{
* Partially presented on colloquium S.F.B.-Diabetes, Nov. 1976, Düsseldorf

1 Present address: Centre de Recherches Clin-Midy, Montpellier, France
}

plex, which is known to code also for immune reactions $[4,5]$.

On the other hand evidence has been established that juvenile diabetes may be initiated by a virus. The mouse model of a virus-induced, insulin-dependent diabetes [6], accompanied by lymphocytic infiltration of the islets of Langerhans [7], and some epidemiological studies [8] support the virus hypothesis.

It is also possible that both mechanisms, the virus infection and the autoimmune reaction, may play a role in the sense that the virus infection initiates an immune reaction leading to a lymphocytic infiltration, "insulitis", with consequent islet destruction. This hypothesis is supported by the finding that mouse strains of different $\mathrm{H}-2$ types in the acute stage of the infection have almost identical necrosis in the majority of B-cells and intact A-cells, but only certain strains (i. e. DBA $_{2}$ develop "insulitis" and diabetes [9]. In the lymphocytic choriomeningitis of the mouse an immune reaction initiated by the virus infection leads to the acute phase of the inflammation and death in adult mice. Therefore the hypothesis that diabetic symptoms provoked by the EMC virus in $\mathrm{DBA}_{2}$ mice might be due to immune reactions was examined.

\section{Materials and Methods}

\section{Mice and Virus}

$\mathrm{DBA}_{2}$ male mice (SPF) from Bomholtsgard, Ry, Denmark were used at the age of 8 and 12 weeks. The EMC virus (M-variant) was obtained from Dr. Craighead and was reproduced by 3 passages on heart tissue [7]. Mice were infected subcutaneously with $0.5 \mathrm{ml}$ heart extract in a dilution of $10^{-2}$ in 
Earles medium. The virus titre in the end dilution was $10^{3,6} \mathrm{TCID}_{50} / 0.25 \mathrm{ml}$. The virus antibodies were determined by haemagglutination inhibition $(\mathrm{HI})$ [10]. Blood glucose levels were determined on nonfasting mice, as fasting was not tolerated very well after infection. Blood samples were taken from the orbit before infection and at weekly intervals thereafter. Glucose was measured on a Technicon autoanalyser using an o-toluidine-method [11].

\section{Immunosuppression}

X-irradiation was performed with the help of Dr. Eichmann from the Institut für Genetik in Köln. With the help of a standard curve, time was calculated to get $500 \mathrm{R}$ per surface occupied by one mouse.

The immunosuppressive drug, Asta 5122, a gift from the Astawerke, was applied $P$ in a daily dose of $0.5 \mathrm{ml}$ of a $1 \mathrm{mg} / \mathrm{ml}$ solution the 6 days following infection (total $=120 \mathrm{mg} / \mathrm{kg}$ ) [12]. This chemical, 3-(2-chloroethyl) -2-(2-mesyloxyethylamino) -tetrahydro-2H-1, 3, 2, -oxazaphosphorine-2-oxide (Asta 5122 ) is a derivative of Cyclophosphamide, known for its immunosuppressive action or, under certain conditions, for the immunostimulation of T-lymphocytes [13-15].

\section{Histopathology}

The pancreata were removed immediately after killing the animals, fixed for a period of 20 hours in Bouin's solution and embedded in paraplast. Evaluation was carried out with $6 \mu$ thick sections, which were stained by Haematoxylin-Eosin. Alpha- and beta-granules were demonstrated by indirect immunofluorescence.

\section{Statistics}

The results of all groups were expressed as means + standard error of means (SEM). The distribution of the individual values for all groups was studied by calculation of their normality, in order to justify the use of the t-test. Calculation of $\beta_{1}$ and $\beta_{2}$ was done by the classical method of Pearson. In a normal distribution $\beta_{1}$ tends to 0 and $\beta_{2}$ to 3 . This had been verified for the experimental values (Table 1-2).

\section{Results}

\section{a) Age Dependence}

Young mice ( 8 weeks) were more resistant to the diabetogenic effects of the virus than older mice. The latter were therefore used in subsequent experi- ments. With increasing mean glucose values the standard deviation increased as well, showing heterogeneity of blood glucose levels in infected mice. 14 days after infection $55 \%$ of the older mice exceeded the level of $257 \mathrm{mg} / 100 \mathrm{ml}$ glucose, the upper normal limit $(=$ mean level +3 times the standard deviation of blood glucose in normal animals).

\section{b) X-Irradiation}

A group of $130 \mathrm{DBA}_{2}$ mice with a mean weight of $22.2 \mathrm{~g}$ was divided into 4 subgroups: 20 mice received the virus only (positive controls), 50 mice Xirradiation plus virus, 50 mice $\mathrm{X}$-irradiation only and 10 mice no treatment (negative controls). The average nonfasting glucose level of mice before the experiment was $163 \pm 4 \mathrm{mg} / 100 \mathrm{ml}$. On day 6 after inoculation the positive control group, receiving virus only, had reached a value of $286 \pm 27 \mathrm{mg} / 100$ $\mathrm{ml}$ in the $95 \%$ surviving animals and on day 14 a mean value of $376 \pm 43 \mathrm{mg} / 100 \mathrm{ml}$ in the $80 \%$ surviving mice. The negative control group with no treatment and the group receiving $\mathrm{X}$-irradiation only had very similar glucose levels with a low standard deviation, but the mean values increased slightly with time.

The experimental group treated with $\mathrm{X}$-irradiation $(500 \mathrm{R})$ plus virus had a mean glucose level almost identical to the negative control group, 169 $\pm 16 \mathrm{mg} / 100 \mathrm{ml}$ in the $82 \%$ surviving animals on day 6 , which is significantly decreased $(\mathrm{p}<0.001)$ in comparison with the positive controls. Thereafter the high mortality rate led to only $10 \%$ of animals surviving by day $14(\mathrm{n}=5)$, with an average glucose concentration identical to the negative control group $(214 \pm 7 \mathrm{mg} / 100 \mathrm{ml})$. The high standard deviation on day 6 demonstrates the presence of some high and some subnormal glucose levels in this group. In the positive control group $42 \%$ of the animals were diabetic (i. e. exceeding 3 times the standard deviation of normal animals), but only $17 \%$ of the mice with virus plus $\mathrm{X}$-irradiation. Histologically no insulitis was found in any of the animals examined, but necrosis was found in the B-cells without infiltrations in $14 / 17$ mice and in the exocrine pancreas in $12 / 17$. This is very uncommon in animals without immune depression (Table 3).

Virus could be cultured from pancreatic tissues in all animals, but the antibody titre against the EMC virus remained negative.

\section{c) Chemical Immunosuppression}

Mice (200) were randomly divided into 4 groups: 40 mice received the virus only (positive control), 100 
Table 1. Immunosuppression by X-irradiation. Nonfasting levels of blood glucose at different times after treatment with: virus alone, virus plus $500 \mathrm{R} \mathrm{X}$-irradiation, $\mathrm{X}$-irradiation alone or no treatment

\begin{tabular}{|c|c|c|c|c|c|c|c|c|c|c|}
\hline $\begin{array}{l}\text { EMC } \\
\text { Virus }\end{array}$ & $\begin{array}{l}\mathrm{X}- \\
\text { Irra- } \\
\text { diat. } \\
500 \mathrm{R}\end{array}$ & $\mathbf{N}$ & $\begin{array}{l}\text { Pretreatment } \\
\text { Glucose } \\
\text { level }^{\mathrm{a}} \\
\text { mg } / 100 \mathrm{ml} \\
\text { Mean + SEM }\end{array}$ & $\begin{array}{l}\text { Day } 6 \\
\% \\
\text { Surviving }\end{array}$ & $\begin{array}{l}\text { Glucose } \\
\text { level } \\
\text { mg/100 ml } \\
\text { Mean + SEM }\end{array}$ & $\begin{array}{l}\text { Normality } \\
\beta_{1} \quad \beta_{2}\end{array}$ & $\begin{array}{l}\text { Signif. } \\
\mathrm{p}\end{array}$ & $\begin{array}{l}\% \\
\text { diabetic } \\
\text { values (F) }\end{array}$ & $\begin{array}{l}\text { Day } 13 \\
\% \\
\text { Surviving }\end{array}$ & $\begin{array}{l}\text { Glucose } \\
\text { level } \\
\text { mg } / 100 \mathrm{ml} \\
\text { Mean + SEM }\end{array}$ \\
\hline $\begin{array}{l}+ \\
+ \\
- \\
-\end{array}$ & $\begin{array}{l}- \\
+ \\
+ \\
-\end{array}$ & $\begin{array}{l}20 \\
50 \\
49 \\
10\end{array}$ & $163 \pm 4$ & $\begin{array}{r}95 \% \\
82 \% \\
100 \% \\
100 \%\end{array}$ & $\begin{array}{l}286 \pm 27 \\
169 \pm 16 \\
166 \pm 5 \\
169 \pm 11\end{array}$ & $\left.\begin{array}{ll}0.85 & 2.67 \\
2.19 & 4.99 \\
0.00 & 3.32 \\
\text { n.d. } & \text { n.d. }\end{array}\right]$ & $\begin{array}{l}<0.001 \\
>0.1 \\
>0.1\end{array}$ & $\begin{array}{r}42 \% \\
17 \% \\
0 \% \\
0 \%\end{array}$ & $\begin{array}{l}80 \% \\
10 \% \\
94 \% \\
80 \%\end{array}$ & $\begin{array}{l}376 \pm 43 \\
214 \pm 7 \\
223 \pm 4 \\
239 \pm 13\end{array}$ \\
\hline
\end{tabular}

a pretreatment glucose levels were only measured on a randomized sample of 50 out of the 129 mice

(F) Values $\geqslant$ mean value $+3 \mathrm{SD}$

Table 2. Chemical immunosuppression with ASTA 5122. Nonfasting levels of blood glucose at different times after treatment with: virus alone, virus plus ASTA $5122(6 \times 0.5 \mathrm{mg})$, Asta 5122 alone or no treatment

\begin{tabular}{|c|c|c|c|c|c|c|c|c|c|c|}
\hline \multirow{2}{*}{$\begin{array}{l}\text { EMC } \\
\text { Virus }\end{array}$} & \multirow{2}{*}{$\begin{array}{l}5122 \\
\text { Asta } \\
6 \times \\
0.5 \mathrm{mg}\end{array}$} & \multirow[t]{2}{*}{$\mathbf{N}$} & \multirow[b]{2}{*}{$\begin{array}{l}\text { Pretreatment } \\
\text { Glucose } \\
\text { level }^{\mathrm{a}} \\
\text { mg/100 ml } \\
\text { Mean + SEM }\end{array}$} & \multicolumn{5}{|l|}{ Day 7} & \multicolumn{2}{|l|}{ Day 15} \\
\hline & & & & $\begin{array}{l}\% \\
\text { Surviving }\end{array}$ & $\begin{array}{l}\text { Glucose } \\
\text { level } \\
\text { mg/100 mg } \\
\text { Mean + SEM }\end{array}$ & $\begin{array}{l}\text { Normality } \\
\beta_{1} \quad \beta_{2}\end{array}$ & $\begin{array}{l}\text { Signif. } \\
\mathrm{p}\end{array}$ & $\begin{array}{l}\% \\
\text { Diabetic } \\
\text { values (F) }\end{array}$ & $\begin{array}{l}\text { \% } \\
\text { Surviving }\end{array}$ & $\begin{array}{l}\text { Glucose } \\
\text { level } \\
\text { mg/100 ml } \\
\text { Mean + SEM }\end{array}$ \\
\hline+ & - & 40 & & $100 \%$ & $367 \pm 21$ & $0.151 .89]$ & & $88 \%$ & $90 \%$ & $392 \pm 25$ \\
\hline+ & + & 100 & $144 \pm 3$ & $40 \%$ & $482 \pm 28$ & 0.622 .75 & $<0,001$ & $88 \%$ & $0 \%$ & \\
\hline- & + & 50 & & $96 \%$ & $123 \pm 4$ & 0.562 .98 & $>0.00$ & $0 \%$ & $90 \%$ & $134 \pm 4$ \\
\hline- & - & 10 & & $100 \%$ & $148 \pm 5$ & n.d. n.d. & & $0 \%$ & $80 \%$ & $151 \pm 5$ \\
\hline
\end{tabular}

a pretreatment glucose levels were only measured on a randomised sample of 50 out of the 200 inbread SPF mice

(F) values $\geqslant$ mean value $+3 \mathrm{SD}$

Table 3. Histology and virology after immunosuppression. Virological and histological findings of infected DBA 2 mice without immunosuppression, after $500 \mathrm{R}$ X-irradiation or after $6 \times 0.5 \mathrm{mg}$ Asta 5122 chemical immunosuppression

\begin{tabular}{|c|c|c|c|c|c|c|c|c|}
\hline \multicolumn{2}{|c|}{ Treatment } & \multicolumn{2}{|c|}{ Examination } & \multicolumn{2}{|l|}{ Virology } & \multicolumn{3}{|c|}{ Histology } \\
\hline Virus & $\begin{array}{l}\text { Immune } \\
\text { suppression }\end{array}$ & Day & $\mathbf{N}$ & $\begin{array}{l}\text { Virus } \\
\text { in } \\
\text { pancreas }\end{array}$ & $\begin{array}{l}\text { HI-anti- } \\
\text { body titer } \\
\text { of } \\
\text { serum }\end{array}$ & Insulitis & $\begin{array}{l}\text { B-Cell } \\
\text { necrosis } \\
\text { without } \\
\text { infiltra- } \\
\text { tion }\end{array}$ & $\begin{array}{l}\text { Exocrine } \\
\text { necrosis }\end{array}$ \\
\hline+ & - & 6 & 20 & $20 / 20$ & $1 />2000$ & $20 / 20$ & $0 / 20$ & $0 / 20$ \\
\hline+ & $\mathrm{X}$-irradiation & $6-8$ & 17 & $17 / 17$ & neg. & $0 / 17$ & $14 / 17$ & $12 / 17$ \\
\hline+ & Asta 5122 & $7-8$ & 20 & $15 / 16$ & not done & $20 / 20$ & $2 / 20$ & $7 / 20$ \\
\hline
\end{tabular}

mice the virus plus Asta 5122 in the dose of 0.5 $\mathrm{mg} / \mathrm{mouse}(20 \mathrm{mg} / \mathrm{kg})$ for 6 days after the virus infection; 50 mice were given Asta 5122 alone for the same period and 10 mice were without treatment (negative controls). The mean glucose level of 144 $\pm 3 \mathrm{mg} / 100 \mathrm{ml}$ resembled that in the former experiment and did not change on days 6 and 13 in the negative controls without treatment or in the group with Asta 5122 only. The positive control group became more rapidly diabetic than in the former experiment $(367 \mathrm{mg} / 100 \mathrm{ml}$ on day 6 and $392 \mathrm{mg} / 100$ $\mathrm{ml}$ on day 14). The experimental group with virus plus Asta 5122 had a higher mortality than the corresponding group after $X$-irradiation as only $40 \%$ survived on day 7 and no animal on day 14 . The average glucose level on day $7(482 \pm 28 \mathrm{mg} / 100$ $\mathrm{ml})$, however, is significantly $(\mathrm{p}<0.01)$ increased in comparison with the group receiving virus only, though the number of diabetic animals $(88 \%)$ is identical in both groups. Most of the animals $(16 / 20)$ showed a severe insulitis, while necrosis without infiltration was only seen in $2 / 20$ mice. Necrosis of the exocrine pancreas was much more frequent $(7 / 20)$. Virus was demonstrated by culture of 
pancreatic tissue in $15 / 16$ animals. Virus antibodies were not determined because of a lack of serum (Table 3).

\section{Discussion}

Participation of immune reactions in virus induced diabetes can be demonstrated by immunosuppression. This procedure, however, simultaneously decreases the hosts defence, thus favouring virus multiplication. In consequence there was a high mortality in mice treated with the EMC-virus ( $M$ variant) plus immunosuppression by $\mathrm{X}$-irradiation or chemicals. Only $10 \%$ of the animals after $X$-irradiation, and no animal after chemical immunosuppression plus virus, survived on day 13 or 15 , respectively. On day 6 there was still a sufficient percentage of surviving mice: $82 \%(n=41)$ for the $X$-irradiated and $40 \%(n=40)$ for the chemically suppressed group for comparative purposes. Mice with 500 R X-irradiation or immunosuppressive chemicals alone had no higher mortality than the negative controls without treatment. On day 6 the immunosuppression by $\mathrm{X}$-irradiation significantly inhibited $(\mathrm{p}<0.001)$ the appearance of diabetes in the EMCvirus infected $\mathrm{DBA}_{2}$ mice. The mean glucose value was the same as that of untreated controls or the group with $\mathrm{X}$-irradiation alone. However the standard deviation of $\pm 105 \mathrm{mg} / 100 \mathrm{ml}$ indicates that a few animals had high glucose levels and a few others subnormal low concentrations. The subnormal values are probably from animals no longer able to eat. When the diabetic animals in both groups were checked, only $17 \%(7 / 41)$ were found in the X-irradiated group, but $42 \%(8 / 19)$ in the positive controls. Preliminary histopathological examination suggests a complete lack of insulitis in all irradiated mice, but islet cell necrosis without lymphocytic infiltration indicated that the virus was present.

The additional lack of antibodies against the EMC virus showed that immunosuppression at the level of T- and B-cells was complete at that period and the necrosis of the islets was presumably due to the toxic effect of the virus. As the necrosis was not sufficient to induce diabetes, an additional reaction of the immune system seems to be necessary for its appearance.

The chemical immunosuppression with the cyclophosphamide derivative Asta 5122 significantly $(\mathrm{p}<0.01)$ increased the mean value of blood glucose levels compared to the positive controls, though the percentage of diabetic animals $(88 \%)$ was the same in both groups. Chemical immunosuppression without virus did not lead to diabetes. In connection with the high blood glucose levels the histological examination showed a very high incidence of severe insulitis.

The antibody titres against EMC virus could not be measured, but, according to the literature, a decrease of antibody production should be expected [12]. Therefore there was a cellular immune response with probably no serological immune response. The preferential depression of the antibody producing B-lymphocytes under certain conditions of treatment with cyclophosphamide was described in 1972 [13] and then confirmed by two other groups [14-15]. The appearance of the lymphocytic infiltration in the islet correlates with a high level of blood glucose. This is quite evident in the chemically immunosuppressed group.

There are other possible interpretations of the data. Thus the $18 \%$ mortality in the virus plus irradiation group could represent animals with severe diabetes. Inclusion of values for such animals could have greatly increased the mean glucose value. The same criticism could apply to the chemical immunosuppression group with a $60 \%$ mortality by day 6 . However, the histopathological findings suggest that the high mortality is not due to diabetes but to an increased myocardial necrosis as there was less destruction of the islet of Langerhans after X-irradiation compared to positive controls.

Immunosuppression may lead to virus multiplication, which may itself exacerbate hyperglycaemia by increases of glucagon and corticosterone secretion. This explanation does not take into account that X-irradiation inhibited high glucose levels despite increased virus multiplication.

The subnormal glucose levels of some animals in the X-irradiated group may have been due to an inability to eat. However, this possibility would be as likely in the more severely affected group with chemical immunosuppression which, nevertheless, had the highest glucose levels of all groups. It cannot alone explain the decreased glucose levels after virus plus $\mathrm{X}$-irradiation.

$\mathrm{X}$-irradiation is known to affect $\mathrm{T}$ - and B-lymphocytes simultaneously. On the other hand cyclophosphamide, under certain conditions, enhances the activation of T-lymphocytes $[13,14,15]$. Therefore the increased insulitis, after drug induced immunosuppression, suggests that a cellular immune response might destroy those $\mathrm{B}$-cells of the islets which escaped the virus attack.

These experiments can only be considered as pilot experiments. They have to be repeated in a way that prevents the high mortality and demonstrates immunological specificity. 
Acknowledgements. We would like to thank Dr. Eichmann, Genetisches Institut, Köln, for his advice and his help in X-irradiation. Excellent technical assistance was effected by A.M. Mariani, D. Simon from Clin-Midy Montpellier and H. Martin from Path. Institute of the University, Düsseldorf. This work was supported by D.F. G. Sonderförschungsbereich Diabetes, Düsseldorf.

\section{References}

1. Bottazzo, G.F., Florin-Christensen, A., Doniach, D.: Islet cell antibodies in diabetes mellitus with autoimmune polyendocrine deficiencies. Lancet 1974 II, 1279-1282

2. MacCuish, A.C., Irvine, W.J., Barnes, E.W., Duncan, L.J.P.: Antibodies to pancreatic islet cells in insulin-dependent diabetics with coexistent autoimmune disease. Lancet 1974 II, 1529-1532

3. Gepts, W.: Pathologic anatomy of the pancreas in juvenile diabetes mellitus. Diabetes 14, 619-633 (1965)

4. Nerup, J., Platz, P., Andersen, O.O., Christy, M., Lyngsoe, J., Poulsen; J. E., Ryder, L. P., Thomsen, M., Staub Nielsen, L., Svejgaard, A.: HL-A antigens and diabetes mellitus. Lancet 1974 II, 864-866

5. Jansen, F.K., Bertrams, J., Grüneklee, D., Drost, H., Reis, H.E., Beyer, J., Kuwert, E., Gries, F. A., Altrock, E.: Genetic association of the insulin-antibody production with histocompatibility (HL-A)-antigens in diabetics. Diabetologia 11 (Abstr.), 352-353 (1975)

6. Craighead, J.E., MacLane, M.F.: Diabetes mellitus: Induction in mice by encephalomyocarditis virus. Science $\mathbf{1 6 2}$, 913-914 (1968)

7. Müntefering, H.: Zur Pathologie des Diabetes mellitus der weißen Maus bei der EMC-Virusinfektion. Histologische, elektronenmikroskopische und quantitativ morphologische Befunde an den Langerhansschen Inseln. Virchows Arch. [Pathol. Anat.] 356, 207-234 (1972)
8. Gamble, D.R., Taylor, K.W.: Epidemiological background to diabetes. Acta Endocrinol. (Kbh.) 83, 161-166 (1976)

9. Müntefering, H., Stueken, E.: Virusinfection and Diabetes mellitus: Fluoreszenzmikroskopischer Nachweis im Pankreas verschiedener Mäusestämme. 10. Kongreß der Deutschen Diabetes-Gesellschaft, Ulm (1975). (Novoinformation, abstr. 49)

10. Craighead, J.E., Shelokov, A.: Encephalomyocarditis virus haemagglutination-inhibition test using antigens prepared in HeLa cell cultures. Proc. Soc. Exp. Biol. Med. 108, 823-826 (1961)

11. Hoffman, W. S.: A rapid photoelectric method for the determination of glucose in blood and urine. J. Biol. Chem. 120, 51-55 (1967)

12. Botzenhardt, U., Lemmel, E. M.: Immunsuppression und Toleranzinduktion durch 3-(2-Chloräthyl)-2-(2-mesyloxyäthylamino)-tetrahydro-2H-1，3，2-oxyzaphosphorin-2-oxid (Asta 5122) Arzneim.-Forsch. 24, 1167-1172 (1974)

13. Turk, J.L., Parker, D., Poulter, L.W.: Functional aspects of the selective depletion of lymphoid tissue by cyclophosphamide. Immunology 23, 493-499 (1972)

14. Stockman, G.D., Heim, L. R., South, M.A., Trentin, J.J.: Differential effects of cyclophosphamide on the B and $T$ cell compartments of adult mice. J. Immunol. 110, 277-282 (1973)

15. Müller-Buchholtz,: Beeinflussung transplantations-immunologischer Reaktionen durch Cyclophosphamid und andere homologe Oxazaphosphorin-2-oxide. Arzneim. Forsch. 24, 1160-1167 (1974)

Reveived: January 28, 1977, and in revised form: May 18, 1977

Dr. F. K. Jansen

Service d'Immunologie

Centre de Recherches Clin Midy

rue du Professeur Blayac

F-34082 Montpellier Cedex

France 